\title{
How Does Firm ESG Performance Impact Financial Constraints? An Experimental Exploration of the COVID-19 Pandemic
}

\author{
Dongyang Zhang ${ }^{1}$ D $\cdot$ Cao Wang ${ }^{1} \cdot$ Yu Dong $^{1}$
}

Accepted: 21 October 2021 / Published online: 3 January 2022

(c) European Association of Development Research and Training Institutes (EADI) 2021

\begin{abstract}
This research assesses the effects of COVID-19-associated shocks on financial constraints and sustainable development goal (SDG) performance to shed light on the impact of SDGs on economic recovery. We construct a large sample of Chinese listed firms from quarterly firm-level accounting data from the China Stock Market \& Accounting Research Database for the period 2019Q1-2021Q1, matched with environmental, social, and governance (ESG) scores, SDG performance from the WIND Database, and complemented with data on cumulative and new cases of COVID-19 from the World Health Organization. We use difference-in-differences to investigate any causal effect from COVID-19. We find that COVID-19 induces financial constraints in firms. Further, differing from the existing literature on the determinants of SDGs, we explore the supportive role of SDG performance on firm financial performance and show that ESG can better describe SDG performance and alleviate financial constraints. Moreover, both internal and external financial intermediaries improve with enhanced ESG performance in overcoming financial constraints. Our findings strongly indicate that a sustainable development strategy facilitates efficient adaptation to financial challenges and assists in overcoming external shocks.
\end{abstract}

Keywords COVID-19 pandemic $\cdot$ Sustainable development goals $\cdot$ ESG performance $\cdot$ Financial constraints

Cao Wang

wonc@cueb.edu.cn

Dongyang Zhang

zhangdongyang@cueb.edu.cn

Yu Dong

dongyu@cueb.edu.cn

1 School of Economics, Capital University of Economics and Business, Beijing, China 


\section{Résumé}

Cette étude évalue les effets des chocs associés à la COVID-19 sur les contraintes financières et la performance des objectifs de développement durable (ODD) pour mettre en lumière l'impact des ODD sur la reprise économique. Nous rassemblons un large échantillon d'entreprises chinoises cotées en Bourse à partir de données comptables trimestrielles émanant de la base de données de recherche sur la comptabilité et sur le marché boursier chinois, du premier trimestre 2019 au premier trimestre 2021. Ces données sont appariées avec des critères environnementaux, sociaux et de gouvernance (ESG), avec la performance des ODD tirée de la base de données WIND, et sont complétées par des données issues de l'Organisation mondiale de la santé sur le nombre de cas cumulatifs et de nouveaux cas de COVID-19. Nous utilisons la méthode des différences de différences pour étudier l'effet de causalité lié à la COVID-19. Nous constatons que la COVID-19 provoque des contraintes financières au sein des entreprises. De plus, contrairement à ce qui est réalisé dans la littérature existante sur les déterminants des ODD, nous explorons le rôle d'appui que jouent les bons résultats des ODD sur la performance financière des entreprises et montrons que les critères ESG permettent de décrire de façon plus adéquate les résultats des ODD et d'alléger les contraintes financières. De plus, les intermédiaires financiers à la fois internes et externes, grâce à de meilleures performances des critères ESG, sont en gré d'améliorer leur réponse aux contraintes financières. Nos résultats fournissent des donnéees probantes selon lesquelles une stratégie de développement durable facilite une adaptation efficiente aux défis financiers et aide à surmonter les chocs externes.

JEL classification D8 · G3 · G31

\section{Introduction}

It is widely discussed that the COVID-19 pandemic has caused an enormous spike in uncertainty and wide-ranging effects on transportation, population mobility, health care, and economies (Baker et al. 2020; Zhang and Hu 2021). As a result, sustainable economic growth has been severely disrupted (Milea 2020; Vidya and Prabheesh 2020; Yoshino and Otsuka 2021). The impact of the COVID-19 pandemic on financial markets has gained much attention (Ali et al. 2020). A rapidly growing body of literature on COVID-19 focuses on the impact of the pandemic on financial markets, including risk (Rizwan et al. 2020), stock market volatility (Baek et al. 2020; Phan and Narayan 2020), firm returns (Shen et al. 2020), and liquidity (Just and Echaust 2020). In contrast, particularly owing to data limitations, exploration of the impact of the COVID-19 pandemic at the firm level is quite limited. Thus, there is a great need to investigate how the pandemic influences corporate financial performance, given the severe global public health crisis.

Given that China is the world's largest developing economy and supplier of intermediate goods, the uncertainty caused by the COVID-19 pandemic has significantly affected a large number of economies worldwide (Milea 2020; Vidya and Prabheesh 2020). Existing studies show the outcomes from the COVID-19 
pandemic in China, including the financial reaction (Xiong et al. 2020; Li et al. 2021) and damage to firm performance (Shen et al. 2020). However, the financial effects of the pandemic are less explored. In particular, the mechanisms and strategies to overcome firm financial constraints need further investigation. This paper sheds light on the supportive mechanisms and the strategies pursued by firms, including sustainable development goals (SDGs), and it provides evidence on the impact of SDG performance on firm financial performance.

The existing literature on the contribution of SDGs to firm performance is limited. The objectives of SDGs are to establish sustainable, innovative strategies, and programs to help in poverty alleviation, employment opportunities, and community support while reducing environmental pollution (Chams and GarciaBlandon 2019; Taghizadeh-Hesary et al. 2021). SDGs have become a collective goal and value of business organizations, government, social organizations, and policymakers (Branco and Rodrigues 2006; Zeug et al. 2019). Further, SDGs have become a top priority of business organizations (Ding et al. 2019). Effective strategies are needed by organizations to attain SDGs (Grainger-Brown and Malekpour 2019). Strong SDG performance sends positive signals to the product and financial markets, helping firms gain market share and financial support. Thus, this paper assesses the supportive impact arising from firm pursuit of SDGs given the shocks associated with the COVID-19 pandemic with respect to financial constraints and financial intermediary performance.

We use financial data disclosed by Chinese listed companies from the China Stock Market \& Accounting Research Database (CSMAR) for the period 2019Q1 to 2021Q1 and environmental, social, and governance (ESG) data representing an enterprise's SDG performance from the WIND Database. In addition, according to the spatial distribution of COVID-19, we distinguish whether enterprises are located in regions with serious epidemics to identify our estimation model. We test whether COVID-19 hurts firm financial performance and quantify the magnitude of the effect. We use difference-in-differences (DID) to investigate the causal effect on financial constraints caused by COVID-19. Further, differing from the existing literature on the determinants of SDGs, we explore the supportive role of SDG performance on firm financial performance. We make several contributions to the literature. First, we provide new evidence on firm-level financial performance caused by the COVID-19 pandemic, and we show that financial constraints are driven by the outbreak. Moreover, we uncover firm financial outcomes using a series of financial constraint indicators and contribute to the growing, but limited understanding of the economic outcomes from the pandemic (Xiong et al. 2020; Hu and Zhang 2021). Second, this paper explores how SDG performance impacts firm performance. More particularly, it provides the new insight that SDGs can improve information asymmetry, thus helping address firm financial constraints (Ding et al. 2019; Zeug et al. 2019). Third, we show that ESG is an effective indicator that well describes SDGs, and we describe the ESG moderating mechanisms on financial constraints, providing new evidence for the recent ESG literature (Friede et al. 2015; Fatemi et al. 2018; Wong et al. 2021).

This paper proceeds as follows. "Literature Review and Hypothesis Development" section presents our research hypotheses in accordance with the literature 
review and discussion. "Data and Summary Statistics" section presents our data sources and variable definitions. "Econometric Specifications" section outlines our econometric strategy. "Empirical Results" section describes our empirical findings, and "Robustness test" section provides a series of robustness tests. Finally, "Conclusions" section concludes with a review our main insights.

\section{Literature Review and Hypothesis Development}

\section{Covid-19 Pandemic and Firm Financial Performance}

The COVID-19 pandemic led to a significant decline in the stock market, and firms worldwide are suffering severe financial difficulties and other problems (Shen et al. 2020; Hu and Zhang 2021). In particular, China has carried out a lot of measures to impede the spread of the virus, making citizens take fewer trips outside, isolate at home, increase social distance and decrease gatherings and crowds (Phan and Narayan 2020; Gu et al. 2020), resulting in a declining labor force and impeding firms from functioning normally (Kyriazis 2021).

The resulting fall in productivity has been matched by a slump in capital markets. Researchers have shown that firms in industries sensitive to the effects of the COVID-19 pandemic suffer significant financial problems and reduced financial returns around the outbreak (Xiong et al. 2020). As a result, the COVID-19 pandemic has brought about a significant adverse impact on firm financial intermediation. In addition, in the most affected countries, Goodell (2020) demonstrates that firms are exposed to tightened financial flexibility and increased financial costs, resulting in tighter financial constraints. Additionally, economic uncertainty is widely recognized to impact decisions on external financial issues, such as bank lending (Hu and Gong 2019). The COVID-19 pandemic has spread globally since the beginning of 2020, and firms are challenged by increased uncertainty as a result (Hassan et al. 2020). Thus, external lenders may more fully consider lending risk, making firms more financially constrained.

Accordingly, we set forth our basic hypothesis as follows.

Hypothesis 1 The COVID-19 pandemic has caused significant financial constraints in listed Chinese firms.

\section{ESG Performance and Financial Constraints}

Information asymmetry between investors and firms is the fundamental cause of firm financial constraints (Banerjee et al. 2020; Chen and Yang 2020; Wong et al. 2021); the COVID-19 pandemic has increased this information asymmetry (Hassan et al. 2020). A higher degree of information asymmetry makes it more difficult for firms to obtain funds (Gu et al. 2020; He et al. 2020). Investors depend on both comprehensive and soft information disclosed by firms when they are issued 
credit, reducing information asymmetry (Garcia et al. 2017). Evidence indicates that there is a negative relationship between corporate social responsibility activities and financial constraints (Garcia et al. 2017; Banerjee et al. 2020).

The ESG performance score is derived from three SDGs, environmental protection, social responsibility and corporate governance; these are generally objective evaluations rated by a third-party rating agency (Wong et al. 2021). ESG performance information can better measure the strength of an enterprise from the perspective of soft information, helping investors judge whether the enterprise merits investment. This has been especially true during the pandemic, which has generated severe information asymmetry (Amel-Zadeh and Serafeim 2018). ESG disclosure activities can increase firm value, thus playing a vital moderating role in mitigating the negative effects of a firm's shortcomings (Brown and Hillegeist 2007; Fatemi et al. 2018; Wong et al. 2021). High ESG scores can improve investor results in their financial portfolios, because better ESG-performing firms are more likely to be ethical but not sacrifice returns, and such firms might be more likely to survive crises in a and sustainable way (Pedersen et al. 2020). Further, due to additional environmental protection costs (Zhang and Vigne 2021), wellfinanced firms are more likely to perform better in environmental protection; thus, these firms have easier access to investment funds, alleviating financial constraints (Banerjee et al. 2020).

This leads to our hypothesis on the ESG performance mechanism.

Hypothesis 2 Strong firm ESG performance can help alleviate the financial constraints caused by the COVID-19 pandemic.

Firm financial intermediaries can be divided mainly into two sectors, internal financing and external financing (Amarjit et al. 2019). When firms are challenged by a catastrophic incident, these two financial intermediaries may be negatively affected (Zhang 2020b). Regarding the causes of external financial constraints, financial scarcity is more likely to lead to high impulsivity and risk-taking (Griskevicius et al. 2013), which results in over-borrowing (Shah et al. 2012) and shifts in moral standards (Sharma et al. 2014). As a result, external financial constraints are created. With respect to internal financial constraints, internal financing is maintained by managers given the need for necessary liquidity, which is used to cover fixed expenses, particularly since the COVID-19 pandemic brought sudden uncertainties to firm production and operations. A certain level of internal financing can help firms avoid decreases in external financing (Opler et al. 1999). Moreover, due to differing capacities of external financing, the level of internal financing is managed in advance to prevent financial gaps caused by lack of external financing (Harford et al. 2014). However, the COVID-19 pandemic has brought about the external financial constraints discussed above, and as it poses a barrier to business transactions, it becomes difficult for enterprises to sell assets and recover accounts (Phan and Narayan 2020), creating additional internal constraints. 
The evidence indicates the positive impact of ESG performance on firm reputation, corporate image and competitive advantage (Tamimi and Sebastianelli 2017). Eccles and Viviers (2011) show that ESG disclosure acts as a proxy for management quality for external investors. Moreover, the three ESG dimensions (Environmental, Social and Governance) allow stakeholders to assess the level of firm transparency, potential and risk (Albarrak et al. 2019). The ability to make non-financial disclosures characteristic of ESG and the increasing attention dedicated by investors (Ahmed et al. 2019) allows us to plausibly expect that positive ESG information alleviates external financial constraints. In addition, the evidence shows that ESG disclosure exerts a non-trivial impact on the cost of debt and allows firms to obtain a reduction in debt costs (Abdi and Omri 2020).

Thus, we present our hypothesis on internal and external financial constraints.

Hypothesis 3 Positive ESG-performing firms alleviate internal and external financial constraints and cost of debt.

\section{Data and Summary Statistics}

\section{Data}

To identify how the COVID-19 pandemic impacts firm financial constraints, we collect quarterly data on listed Chinese firms from CSMAR for the period 2019Q1 to 2021Q1, match the ESG scores for each firm from the WIND Database, and complement this with data on cumulative cases and new cases of COVID-19 from the World Health Organization, yielding a large Chinese listed enterprise database.

The important features of this database are as follows. First, our database is comprehensive, and large samples can decrease the probability of biased estimation. Second, our samples contain broad variables, including firm characteristics and financial variables. Thus, we can test more mechanisms in our models and better overcome the omitted variables problem. Third, we use quarterly data that include two complete years in the same business cycle. ${ }^{1}$

\section{Descriptive Statistics}

This subsection presents a statistical summary of the variables. Table 1 presents the summary statistics of the main variables. We distinguish the control group from the treatment group by whether they were affected by the pandemic as measured by Treat, and we use Post to indicate whether the time is before or after the pandemic.

\footnotetext{
1 According to Granziera and Sekhposyan (2019), business cycle indicators, financial conditions, uncertainty, and measures of past relative performances are generally useful for explaining models' estimation performance and efficiency. Through the comparison of ESG performance on financial constraints before and after COVID-19, we select data during 2019Q1 to 2020Q4, which has a more convenient and intuitive understanding of the impact of COVID-19 on the performance of listed firms (Shen et al. 2020).
} 
Table 1 Descriptive statistics

\begin{tabular}{|c|c|c|c|c|c|}
\hline \multirow[t]{2}{*}{ Variable } & (1) & (2) & (3) & (4) & (5) \\
\hline & $N$ & Mean & $\mathrm{SD}$ & Min & $\operatorname{Max}$ \\
\hline Post & 45,236 & 0.345 & 0.275 & 0 & 1 \\
\hline Treat & 45,236 & 0.414 & 0.493 & 0 & 1 \\
\hline WW index & 15,459 & 1.173 & 0.110 & 0.845 & 1.338 \\
\hline $\mathrm{KZ}$ index & 14,672 & 6.605 & 1.042 & 4.021 & 9.089 \\
\hline Liquidity & 22,349 & 0.232 & 0.251 & -0.438 & 0.803 \\
\hline SA index & 22,882 & 5.098 & 1.838 & 2.138 & 11.910 \\
\hline ESG & 26,293 & 6.273 & 1.336 & 1 & 9 \\
\hline Tobin's $Q$ & 22,770 & 1.981 & 1.912 & 0.560 & 48.330 \\
\hline Sales growth & 38,548 & 0.508 & 0.821 & -0.921 & 3.299 \\
\hline Firm size & 42,498 & 22.38 & 1.469 & 19.71 & 27.37 \\
\hline Current ratio & 22,359 & 2.508 & 2.553 & 0.317 & 16.47 \\
\hline Short-term debt ratio & 22,277 & 0.339 & 0.180 & 0.040 & 0.869 \\
\hline Long-term debt ratio & 15,527 & 0.096 & 0.096 & 0.001 & 0.457 \\
\hline Firm age & 25,533 & 2.130 & 0.904 & 0 & 3.401 \\
\hline Management cost & 22,859 & 0.960 & 0.266 & 0.396 & 2.622 \\
\hline ROA & 22,872 & 0.022 & 0.044 & -0.187 & 0.154 \\
\hline ROE & 22,735 & 0.065 & 0.224 & -0.454 & 1.444 \\
\hline
\end{tabular}

We use WW index, KZ index, liquidity, and SA (Size-age) index to measure firm financial constraints in different dimensions. The key independent variable is ESG score, which is assigned a value from 1 to 9; the higher the ESG score, the better the firm social responsibility performance.

We also consider many control variables that might impact firm financial performance. Tobin's $Q$ is a ratio of firm market value that shows its replacement value; it can also be used to measure whether a firm is overvalued or undervalued in the market. Sales growth reflects a firm's growth potential in the market, and is positive when the firm gains market share. In addition, we take into account firm size as a control variable, because it may have a significant relationship with the degree of financial constraint, and rich evidence indicates that larger firms have lower financial constraints (e.g., Zhang 2021). The current ratio shows firm performance from the perspective of inflow and outflow of funds; higher current ratio can indicate that the firm is facing fewer financial difficulties. As for short-term debt ratio and long-term debt ratio, firms with low financial constraints may have better loan positions when confronting a sudden crisis, and it may be easier for them to get financial help than for companies with high financial constraints. Figure 1 shows that total external debt is affected by the COVID-19 pandemic, especially for the treatment group of firms strongly impacted by the pandemic. In addition, management cost shows the cost of firm production and operational activities; the lower the cost, the better performance for enterprises of the same scale. As for profitability [return on assets (ROA) and return on equity (ROE)], a 


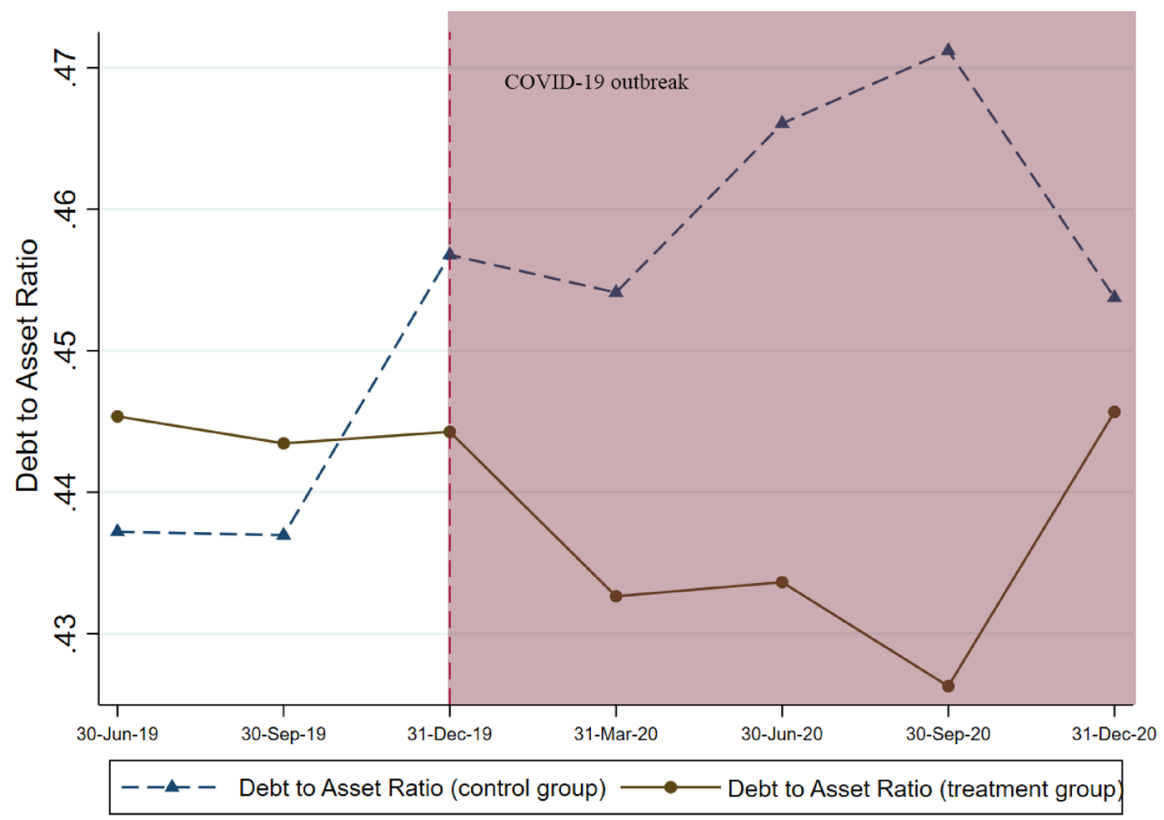

Fig. 1 Total debt ratio between treatment and control groups

positive value shows that firms perform better in gaining profit, while negative values indicate the opposite.

\section{Econometric Specifications}

The DID estimation strategy is generally employed to estimate different outcomes between treatment and control groups with respect to shocks (Zhang 2020a, 2021). Specifically, we employ the DID econometric model to explore whether the COVID19 pandemic exacerbates firm financial constraints.

Our DID econometric specification can be described as follows:

Financial Constraints $_{i, t}=\alpha_{0}+\beta_{1} \cdot$ Post $_{t}+\beta_{2} \cdot$ Treat $_{i}+\beta_{3} \cdot$ Post $_{t} \cdot$ Treat $_{i}+\beta_{i} X_{i, t}+v_{j}+v_{r}+\varepsilon_{i, t}$

where Financial Constraints ${ }_{i, t}$ are measurements of financial constraints that describe firm financial status. We use both the WW index (Whited and Wu 2006) and the KZ index (Lamont et al. 2001) as our main dependent variables. Moreover, we set Post and Treat variables to measure COVID-19 pandemic effects on financial constraints. We set Post equal to 1 if time is after a critical date for COVID-19, otherwise Post is set to 0 . We further set Treat equal to 1 if a firm is strongly shocked in the pandemic outbreak. Following Gu et al. (2020), we set firms whose input in the first quarter of 2020 is significantly reduced compared to the first quarter of 2019, and the reduction is higher than the average level by industry as treatment groups; 
others are divided into control groups. Post-Treat is the DID effect we focus on in the estimation strategy. In addition, $X_{i, t}$ are the control variables, including basic firm characteristics, such as Tobin's $Q$, sales growth and firm size. Industry and time fixed effects are also controlled in our estimations. $\varepsilon_{i, t}$ are the error terms. $\beta_{3}$ is our target variable; it well describes the effects on financial constraints caused by the COVID-19 pandemic.

Further, to explore the ESG performance mechanisms that alleviate the financial constraints caused by the COVID-19 pandemic, we set our econometric specifications as follows.

$$
\begin{aligned}
\text { Financial Constraints }_{i, t}= & \alpha_{0}+\beta_{1} \cdot \text { Post }_{t}+\beta_{2} \cdot \text { Treat }_{i}+\beta_{3} \cdot \text { Post }_{t} \cdot \text { Treat }_{i}+ \\
& \beta_{4} \cdot \text { Post }_{t} \cdot \text { Treat }_{i} \cdot \mathrm{ESG}_{i, t}+\beta_{5} \cdot \mathrm{ESG}_{i, t}+\beta_{i} X_{i, t}+v_{j}+v_{r}+\varepsilon_{i, t}
\end{aligned}
$$

$\beta_{4}$ is our target variable, and it well describes the ESG mechanism. The ESG performance score is accessed from the WIND Database, which credits each listed firm's ESG performance.

The indicators of firm financial performance are estimated as follows.

$$
\begin{aligned}
\text { Current Ratio }_{i, t}= & \alpha_{0}+\beta_{1} \cdot \text { Post }_{t}+\beta_{2} \cdot \text { Treat }_{i}+\beta_{3} \cdot \text { Post }_{t} \cdot \text { Treat }_{i}+\beta_{4} \\
& \cdot \text { Post }_{t} \cdot \text { Treat }_{i} \cdot \mathrm{ESG}_{i, t}+\beta_{5} \cdot \mathrm{ESG}_{i, t}+\beta_{i} X_{i, t}+v_{j}+v_{r}+\varepsilon_{i, t}
\end{aligned}
$$

Short-term Debt Ratio ${ }_{i, t}=\alpha_{0}+\beta_{1} \cdot$ Post $_{t}+\beta_{2} \cdot$ Treat $_{i}+\beta_{3} \cdot$ Post $_{t} \cdot$ Treat $_{i}+\beta_{4}$

$$
\text { . } \text { Post }_{t} \cdot \text { Treat }_{i} \cdot \mathrm{ESG}_{i, t}+\beta_{5} \cdot \mathrm{ESG}_{i, t}+\beta_{i} X_{i, t}+v_{j}+v_{r}+\varepsilon_{i, t}
$$

Long-term Debt Ratio ${ }_{i, t}=\alpha_{0}+\beta_{1} \cdot$ Post $_{t}+\beta_{2} \cdot$ Treat $_{i}+\beta_{3} \cdot$ Post $_{t} \cdot$ Treat $_{i}+\beta_{4}$

$$
\cdot \text { Post }_{t} \cdot \text { Treat }_{i} \cdot \mathrm{ESG}_{i, t}+\beta_{5} \cdot \mathrm{ESG}_{i, t}+\beta_{i} X_{i, t}+v_{j}+v_{r}+\varepsilon_{i, t}
$$

Management Cost $_{i, t}=\alpha_{0}+\beta_{1} \cdot$ Post $_{t}+\beta_{2} \cdot$ Treat $_{i}+\beta_{3} \cdot$ Post $_{t} \cdot$ Treat $_{i}+\beta_{i} X_{i, t}+v_{j}+v_{r}+\varepsilon_{i, t}$

\section{Empirical Results}

\section{Baseline Results}

Using Eq. (1), we estimate our baseline and report our findings in Table 2. The WW index and $\mathrm{KZ}$ index are used to represent the degree of financing constraint faced by firms, separately. Columns 1 and 2 show the regression result of the explained variable using the WW index, and columns 3 and 4 show the regression result of the explained variable useing the KZ index. Columns 1 and 3 present the estimations without control variables. We find that regardless of whether the WW index or the $\mathrm{KZ}$ index is selected as a measure of financing constraints, the coefficient of the cross-term Post*Treat is significantly positive, which means that the outbreak of 
Table 2 Baseline regression results by measurement of financial constraint

\begin{tabular}{lllll}
\hline Variable & $(1)$ & $\begin{array}{l}(2) \\
\text { Financial constraints }=\mathrm{WW} \text { index }\end{array}$ & $\begin{array}{l}(3) \\
\text { Financial constraints }=\mathrm{KZ} \\
\text { index }\end{array}$ \\
\hline Post & $0.004^{* * *}$ & $0.017^{* *}$ & $-0.143^{* * *}$ & $-0.165^{* * *}$ \\
Treat & $(0.000)$ & $(0.003)$ & $(0.019)$ & $(0.018)$ \\
& $0.010^{* * *}$ & $0.009^{* * *}$ & $-0.159^{* * *}$ & $-0.180^{* * * *}$ \\
Post $\times$ treat & $(0.000)$ & $(0.001)$ & $(0.043)$ & $(0.039)$ \\
& $0.002^{* * *}$ & $0.001^{*}$ & $0.175^{* * *}$ & $0.186^{* * *}$ \\
Tobin's $Q$ & $(0.000)$ & $(0.000)$ & $(0.030)$ & $(0.027)$ \\
& & $-0.005^{* * *}$ & & -0.001 \\
Sales growth & & $(0.000)$ & & $(0.007)$ \\
& & $-0.010^{*}$ & & -0.008 \\
Firm size & & $(0.003)$ & & $(0.009)$ \\
& & $0.013^{* * *}$ & & $0.440^{* * *}$ \\
Constant & & $(0.000)$ & & $(0.005)$ \\
& & $0.697 * *$ & $7.345^{* * *}$ & $-3.176^{* * *}$ \\
Industry fixed effects & Yes & $(0.013)$ & $(0.416)$ & $(0.128)$ \\
Time fixed effects & Yes & Yes & Yes & Yes \\
Observations & $1.162^{* * *}$ & 15,459 & 14,672 & Yes \\
$R^{2}$ & 0.014 & 0.204 & 0.026 & 14,672 \\
\hline
\end{tabular}

Robust standard errors in parentheses

$* * * p<0.01, * * p<0.05, * p<0.1$

the new COVID-19 pandemic has a positive and significant impact on firm financial constraints (at a 1\% significance level). Columns 2 and 4 show the regression results including the control variables. The coefficients of the COVID-19 shock on financial constraints are reported as significantly positive in columns 2 and 4 . We find that firm growth can significantly alleviate financial constraints, and there is a negative relationship between firm size and financial constraints. Moreover, Fig. 2 shows that financial constraints, measured by the $\mathrm{KZ}$ index, are strengthened for firms that suffer badly from the pandemic, and Fig. 3 presents the same trend for firms whose financial constraints are measured by the WW index. Figures 2 and 3 also support our findings that the financial constraints are caused by the COVID19 pandemic. Overall, the results shown in Table 2 support Hypothesis 1 that the impact of COVID-19 has led to increased firm financial constraints. 


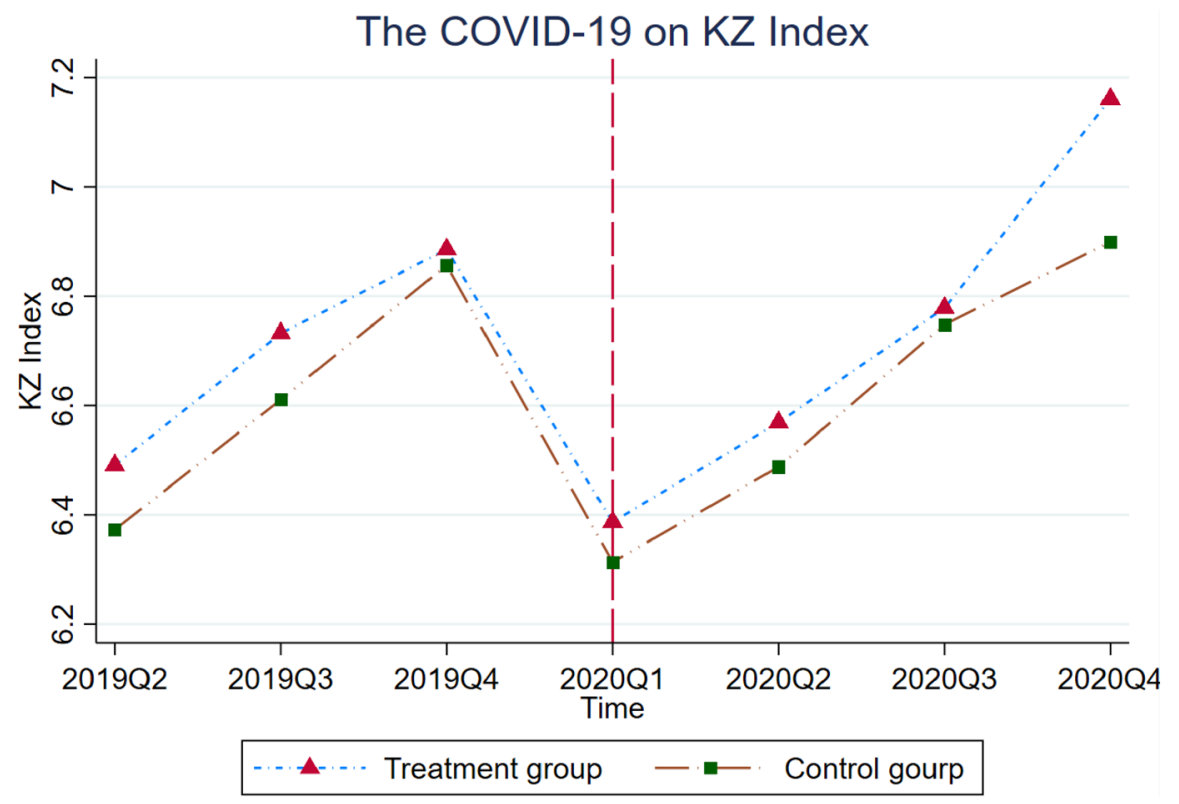

Fig. $2 \mathrm{KZ}$ index trend

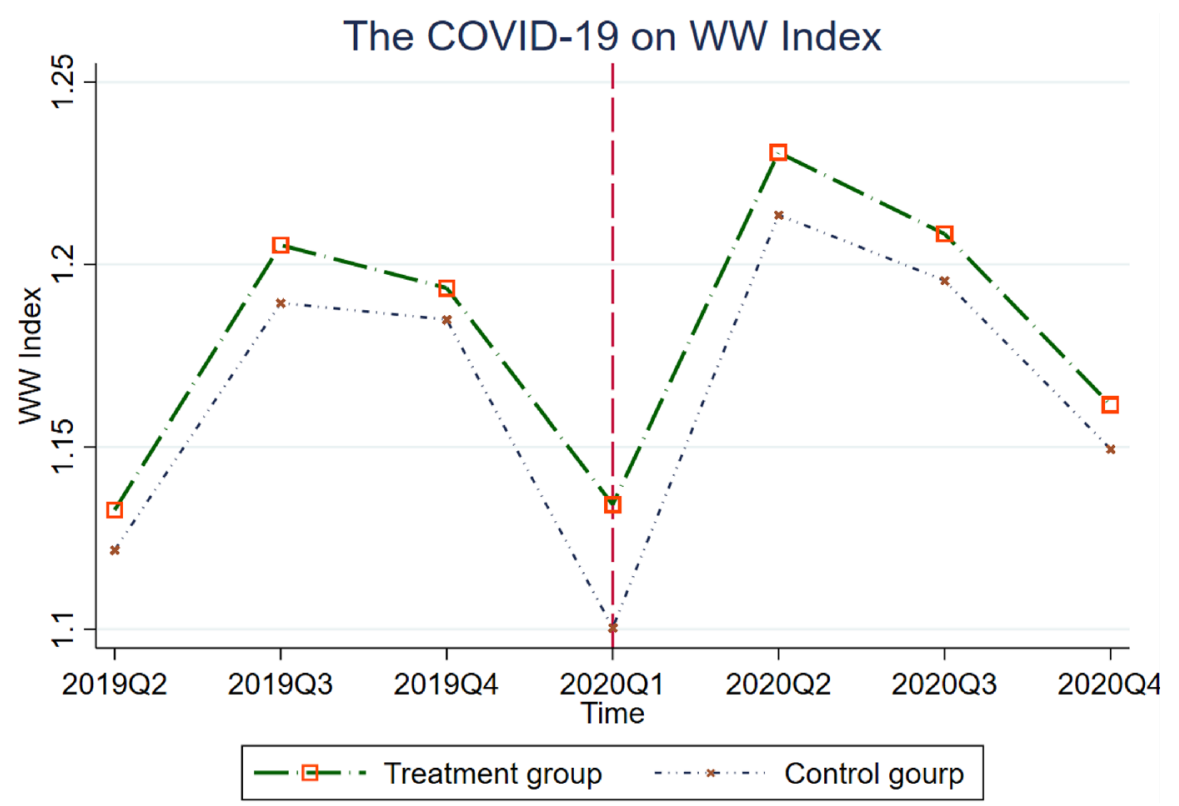

Fig. 3 WW index trend 
Table 3 Regression results of ESG moderating effects

\begin{tabular}{|c|c|c|c|c|}
\hline \multirow[t]{2}{*}{ Variable } & (1) & (2) & (3) & (4) \\
\hline & \multicolumn{2}{|c|}{ Financial constraints $=\mathrm{WW}$ index } & \multicolumn{2}{|c|}{$\begin{array}{l}\text { Financial constraints }=\mathrm{KZ} \\
\text { index }\end{array}$} \\
\hline \multirow[t]{2}{*}{ Post } & -0.005 & $-0.036^{* * *}$ & $-0.236^{* *}$ & $-0.236^{* *}$ \\
\hline & $(0.009)$ & $(0.002)$ & $(0.036)$ & $(0.030)$ \\
\hline \multirow[t]{2}{*}{ Treat } & -0.048 & $0.008 * * *$ & -0.094 & -0.083 \\
\hline & $(0.021)$ & $(0.000)$ & $(0.090)$ & $(0.091)$ \\
\hline \multirow[t]{2}{*}{ Post $\times$ treat } & $0.087 * *$ & $0.004 * *$ & $0.252 * * *$ & 0.209 \\
\hline & $(0.010)$ & $(0.000)$ & $(0.018)$ & $(0.074)$ \\
\hline \multirow[t]{2}{*}{ Post $\times$ treat $\times \mathrm{ESG}$} & $-0.006 * * *$ & $-0.001 *$ & $-0.019 *$ & $-0.015^{*}$ \\
\hline & $(0.001)$ & $(0.000)$ & $(0.005)$ & $(0.005)$ \\
\hline \multirow[t]{2}{*}{ ESG } & $-0.005^{*}$ & $-0.003^{* *}$ & $-0.147 * * *$ & $-0.038^{*}$ \\
\hline & $(0.002)$ & $(0.001)$ & $(0.006)$ & $(0.011)$ \\
\hline \multirow[t]{2}{*}{ Tobin's $Q$} & & $-0.004 * *$ & & 0.002 \\
\hline & & $(0.001)$ & & $(0.010)$ \\
\hline \multirow[t]{2}{*}{ Sales growth } & & -0.009 & & 0.033 \\
\hline & & $(0.003)$ & & $(0.039)$ \\
\hline \multirow[t]{2}{*}{ Firm size } & & $0.014 * * *$ & & $0.458 * * *$ \\
\hline & & $(0.000)$ & & $(0.005)$ \\
\hline \multirow[t]{2}{*}{ Constant } & $1.144 * * *$ & $0.802 * * *$ & $6.066^{* * * *}$ & $-3.190 * * *$ \\
\hline & $(0.007)$ & $(0.008)$ & $(0.063)$ & $(0.120)$ \\
\hline Industry fixed effects & Yes & Yes & Yes & Yes \\
\hline Time fixed effects & Yes & Yes & Yes & Yes \\
\hline Observations & 15,459 & 15,459 & 14,672 & 14,672 \\
\hline$R^{2}$ & 0.039 & 0.193 & 0.047 & 0.329 \\
\hline
\end{tabular}

Robust standard errors in parentheses

$* * * p<0.01, * * p<0.05, * p<0.1$

\section{ESG Performance Moderates Financial Constraint Mechanism}

We investigate whether firm SDGs can alleviate financial constraints when the COVID-19 outbreak has a significant negative impact on firm financial performance. We use ESG scores to measure firm performance. According to the estimated results in Table 3, the ESG coefficients are all negative, indicating that there is a significant negative relationship between ESG score and financial constraints. In other words, better performance on firm SDGs can improve financial constraints. The estimated coefficients of the interaction term Post*Treat*ESG in Table 3 are all significantly negative, with a marginal effect of $0.1 \%$ and $0.15 \%$ in alleviating financial constraints, indicating that following the impact of the COVID-19 pandemic, firms can improve their ESG performance to ease financial constraints, thereby supporting Hypothesis 2. 
Table 4 Regression results of ESG moderating effects on financial performance

\begin{tabular}{|c|c|c|c|}
\hline \multirow[t]{2}{*}{ Variable } & (1) & (2) & (3) \\
\hline & Current ratio & Short-term debt ratio & Long-term debt ratio \\
\hline \multirow[t]{2}{*}{ Post } & -0.051 & 0.003 & $0.005 * * *$ \\
\hline & $(0.060)$ & $(0.003)$ & $(0.000)$ \\
\hline \multirow[t]{2}{*}{ Treat } & $-0.030 * *$ & 0.011 & $0.008 * * *$ \\
\hline & $(0.003)$ & $(0.008)$ & $(0.000)$ \\
\hline \multirow[t]{2}{*}{ Post $\times$ treat } & $-0.320 * *$ & $-0.010^{*}$ & $-0.011^{*}$ \\
\hline & $(0.051)$ & $(0.005)$ & $(0.003)$ \\
\hline \multirow[t]{2}{*}{ Post $\times$ treat $\times$ ESG } & $0.047 * *$ & $0.001 *$ & $0.002 *$ \\
\hline & $(0.009)$ & $(0.000)$ & $(0.000)$ \\
\hline \multirow[t]{2}{*}{ ESG } & $0.230 * *$ & $-0.028 * * *$ & $-0.002 * *$ \\
\hline & $(0.023)$ & $(0.001)$ & $(0.000)$ \\
\hline \multirow[t]{2}{*}{ Tobin's $Q$} & 0.048 & $0.003 * *$ & $-0.003 * *$ \\
\hline & $(0.022)$ & $(0.001)$ & $(0.001)$ \\
\hline \multirow[t]{2}{*}{ Sales growth } & $-0.175^{* *}$ & $0.007 * * *$ & 0.001 \\
\hline & $(0.018)$ & $(0.001)$ & $(0.000)$ \\
\hline \multirow[t]{2}{*}{ Firm size } & $-0.696^{* * *}$ & $0.051 * * *$ & $0.022 * * *$ \\
\hline & $(0.018)$ & $(0.001)$ & $(0.001)$ \\
\hline \multirow[t]{2}{*}{ Constant } & $17.018 * * *$ & $-0.638 * * *$ & $-0.390 * * *$ \\
\hline & $(0.669)$ & $(0.022)$ & $(0.033)$ \\
\hline Industry fixed effects & Yes & Yes & Yes \\
\hline Time fixed effects & Yes & Yes & Yes \\
\hline Observations & 18,579 & 21,688 & 12,941 \\
\hline$R^{2}$ & 0.133 & 0.129 & 0.114 \\
\hline
\end{tabular}

Robust standard errors in parentheses

$* * * p<0.01, * * p<0.05, * p<0.1$

\section{ESG Performance Moderates Financial Performance Mechanism}

To explore how ESG performance alleviates financial constraints, Table 4 presents the relationship between firm ESG performance and financial intermediation during the COVID-19 pandemic. Financial intermediation, including current ratio, short-term debt ratio and long-term debt ratio are discussed in our estimations. As shown in Table 4, all the coefficients of the interaction Post *Treat are negative with marginal effects of $4.7 \%, 0.1 \%$ and $0.2 \%$, illustrating that the COVID-19 pandemic significantly reduces financial intermediation. However, the interactions of Post*Treat*ESG are all positive, indicating that after the COVID19 outbreak, firms can increase their liquidity ratio, short-term debt ratio, and long-term debt ratio through improving their ESG performance. In other words, firms can mitigate the negative impact of COVID-19 on their financial performance by improving their own SDG performance. 
Table 5 Regression results of firm performance mechanisms

\begin{tabular}{|c|c|c|c|c|c|c|}
\hline \multirow[t]{2}{*}{ Variable } & \multicolumn{3}{|l|}{ (1) } & (3) & \multicolumn{2}{|l|}{ (4) } \\
\hline & \multicolumn{3}{|c|}{ Financial constraints $=\mathrm{WW}$ index } & \multicolumn{3}{|c|}{ Financial constraints $=\mathrm{KZ}$ index } \\
\hline \multicolumn{7}{|l|}{ Panel A } \\
\hline Management cost & $\begin{array}{l}0.003 * * * \\
(0.001)\end{array}$ & & & $\begin{array}{l}0.025 * * \\
(0.010)\end{array}$ & & \\
\hline ROA & & $\begin{array}{l}-0.020^{* *} \\
(0.010)\end{array}$ & & & $\begin{array}{l}-0.283^{* *} \\
(0.137)\end{array}$ & \\
\hline ROE & & & $\begin{array}{l}-0.001 * * * \\
(0.000)\end{array}$ & & & $\begin{array}{l}-0.012 * * * \\
(0.002)\end{array}$ \\
\hline Tobin's $Q$ & $\begin{array}{l}-0.005^{* * *} \\
(0.001)\end{array}$ & $\begin{array}{l}-0.005^{* * *} \\
(0.001)\end{array}$ & $\begin{array}{l}-0.005^{* * *} \\
(0.001)\end{array}$ & $\begin{array}{l}-0.009 \\
(0.008)\end{array}$ & $\begin{array}{l}-0.015^{* *} \\
(0.008)\end{array}$ & $\begin{array}{l}-0.009 \\
(0.008)\end{array}$ \\
\hline Sales growth & $\begin{array}{l}-0.011^{\text {*** }} \\
(0.002)\end{array}$ & $\begin{array}{l}-0.010^{* * *} \\
(0.002)\end{array}$ & $\begin{array}{l}-0.010^{* * *} \\
(0.002)\end{array}$ & $\begin{array}{l}-0.034^{*} \\
(0.017)\end{array}$ & $\begin{array}{l}-0.030 * \\
(0.017)\end{array}$ & $\begin{array}{l}-0.032 * \\
(0.017)\end{array}$ \\
\hline Firm size & $\begin{array}{l}0.013 * * * \\
(0.001)\end{array}$ & $\begin{array}{l}0.013 * * * \\
(0.001)\end{array}$ & $\begin{array}{l}0.013 * * * \\
(0.001)\end{array}$ & $\begin{array}{l}0.436 * * * \\
(0.005)\end{array}$ & $\begin{array}{l}0.435 * * * \\
(0.005)\end{array}$ & $\begin{array}{l}0.435 * * * \\
(0.005)\end{array}$ \\
\hline Constant & $\begin{array}{l}0.728 * * * \\
(0.018)\end{array}$ & $\begin{array}{l}0.676^{* * * *} \\
(0.017)\end{array}$ & $\begin{array}{l}0.676^{* * * *} \\
(0.017)\end{array}$ & $\begin{array}{l}-2.523^{* * *} \\
(0.329)\end{array}$ & $\begin{array}{l}-3.083^{* * * *} \\
(0.323)\end{array}$ & $\begin{array}{l}-2.486^{\text {*** }} \\
(0.328)\end{array}$ \\
\hline Industry fixed effects & Yes & Yes & Yes & Yes & Yes & Yes \\
\hline Time fixed effects & Yes & Yes & Yes & Yes & Yes & Yes \\
\hline Observations & 15,420 & 15,425 & 15,367 & 14,664 & 14,669 & 14,611 \\
\hline$R^{2}$ & 0.202 & 0.204 & 0.202 & 0.356 & 0.361 & 0.357 \\
\hline \multirow[t]{2}{*}{ Variable } & \multicolumn{3}{|c|}{ (1) } & \multicolumn{2}{|l|}{ (2) } & (3) \\
\hline & \multicolumn{3}{|c|}{ Management cost } & \multicolumn{2}{|l|}{ ROA } & ROE \\
\hline \multicolumn{7}{|l|}{ Panel B } \\
\hline Post & \multicolumn{3}{|c|}{0.076} & \multicolumn{2}{|l|}{$(0.004)$} & $\begin{array}{l}0.257^{*} \\
(0.063)\end{array}$ \\
\hline Treat & \multicolumn{3}{|c|}{$\begin{array}{l}-0.083^{* *} \\
(0.019)\end{array}$} & \multicolumn{2}{|l|}{$\begin{array}{l}0.044 * * * \\
(0.001)\end{array}$} & $\begin{array}{l}0.375^{* * *} \\
(0.005)\end{array}$ \\
\hline Post $\times$ treat & \multicolumn{3}{|c|}{$\begin{array}{l}0.079 * * * \\
(0.002)\end{array}$} & \multicolumn{2}{|l|}{$\begin{array}{l}-0.029 * * * \\
(0.000)\end{array}$} & $\begin{array}{l}-0.217^{* * *} \\
(0.003)\end{array}$ \\
\hline Tobin's $Q$ & \multicolumn{3}{|c|}{0.110} & \multicolumn{2}{|l|}{$(0.006)$} & $\begin{array}{l}-0.011 \\
(0.005)\end{array}$ \\
\hline Sales growth & \multicolumn{3}{|c|}{-0.052} & $\begin{array}{l}0.011 * * \\
(0.001)\end{array}$ & & $\begin{array}{l}0.082 \\
(0.034)\end{array}$ \\
\hline Firm size & & $\begin{array}{l}-0.041 \\
(0.020)\end{array}$ & & $\begin{array}{l}0.001 \\
(0.001)\end{array}$ & & $\begin{array}{l}0.004 \\
(0.006)\end{array}$ \\
\hline Constant & & $\begin{array}{l}1.645^{*} \\
(0.413)\end{array}$ & & $\begin{array}{l}-0.069^{*} \\
(0.017)\end{array}$ & & $\begin{array}{l}-0.416^{*} \\
(0.121)\end{array}$ \\
\hline Industry fixed effects & & Yes & & Yes & & Yes \\
\hline Time fixed effects & & Yes & & Yes & & Yes \\
\hline Observations & & 22,593 & & 22,600 & & 22,495 \\
\hline$R^{2}$ & & 0.013 & & 0.008 & & 0.002 \\
\hline
\end{tabular}

Robust standard errors in parentheses

$* * * p<0.01, * * p<0.05, * p<0.1$ 
Table 6 Robustness test-regression results of placebo effect

\begin{tabular}{|c|c|c|c|c|}
\hline \multirow[t]{2}{*}{ Variable } & (1) & (2) & (3) & (4) \\
\hline & \multicolumn{2}{|c|}{ Financial constraints $=\mathrm{WW}$ index } & \multicolumn{2}{|c|}{$\begin{array}{l}\text { Financial constraints }=\mathrm{KZ} \\
\text { index }\end{array}$} \\
\hline \multirow[t]{2}{*}{ Post } & $0.069 * *$ & $0.059 * *$ & 0.098 & 0.102 \\
\hline & $(0.022)$ & $(0.023)$ & $(0.150)$ & $(0.131)$ \\
\hline \multirow[t]{2}{*}{ Treat } & 0.056 & 0.039 & 0.277 & $0.284 * *$ \\
\hline & $(0.054)$ & $(0.035)$ & $(0.146)$ & $(0.112)$ \\
\hline \multirow[t]{2}{*}{ Post $\times$ treat } & $-0.055^{*}$ & $-0.048 * *$ & $-0.319 * *$ & $-0.381 * *$ \\
\hline & $(0.023)$ & $(0.018)$ & $(0.101)$ & $(0.141)$ \\
\hline \multirow[t]{2}{*}{ Pre-post $\times$ treat } & 0.024 & 0.028 & 0.209 & 0.269 \\
\hline & $(0.028)$ & $(0.028)$ & $(0.117)$ & $(0.187)$ \\
\hline \multirow[t]{2}{*}{ Tobin's $Q$} & & $-0.006^{* * *}$ & & -0.007 \\
\hline & & $(0.001)$ & & $(0.007)$ \\
\hline \multirow[t]{2}{*}{ Sales growth } & & 0.010 & & -0.042 \\
\hline & & $(0.015)$ & & $(0.084)$ \\
\hline \multirow[t]{2}{*}{ Firm size } & & $0.008 * * *$ & & $0.437 * * *$ \\
\hline & & $(0.001)$ & & $(0.006)$ \\
\hline \multirow[t]{2}{*}{ Constant } & $1.075 * * *$ & $0.912 * * *$ & $6.440 * * *$ & $-3.459 * * *$ \\
\hline & $(0.042)$ & $(0.047)$ & $(0.251)$ & $(0.333)$ \\
\hline Industry fixed effects & Yes & Yes & Yes & Yes \\
\hline Time fixed effects & Yes & Yes & Yes & Yes \\
\hline Observations & 15,459 & 15,459 & 14,672 & 14,672 \\
\hline$R^{2}$ & 0.076 & 0.100 & 0.008 & 0.329 \\
\hline
\end{tabular}

Robust standard errors in parentheses

$* * * p<0.01, * * p<0.05, * p<0.1$

\section{Firm Performance Mechanism}

We explore the firm performance mechanism with respect to financial constraints induced by the COVID-19 outbreak. Table 5, Panel A, first investigates the relationship between firm performance and financial constraints. We use management cost, ROA and ROE to measure firm performance, separately. The estimation results show that management cost induces more financial constraints, while higher profitability can alleviate financial constraints. Table 5, Panel B, further shows the impact of the COVID-19 pandemic on firm performance, which includes indicators such as management cost and profitability (return on assets and return on equity). The coefficient of the interaction Post*Treat in column 1 of Table 5 is 0.079 , significant at the $1 \%$ level, indicating that firm management cost increases following the outbreak of COVID-19. In addition, columns 2 and 3 indicate the impact of the COVID-19 outbreak on firm profitability. The Post*Treat coefficients are all negative, indicating that firm profitability decreases after the COVID-19 outbreak. These findings 
Table 7 Robustness test-regression results of alternative measurements of financial constraint

\begin{tabular}{|c|c|c|c|c|}
\hline \multirow[t]{2}{*}{ Variable } & (1) & (2) & (3) & (4) \\
\hline & \multicolumn{2}{|c|}{ Financial constraints = liquidity } & \multicolumn{2}{|c|}{$\begin{array}{l}\text { Financial constraints }=\mathrm{SA} \\
\text { index }\end{array}$} \\
\hline Post & $\begin{array}{l}0.010 * * * \\
(0.000)\end{array}$ & $\begin{array}{l}0.018 * * * \\
(0.001)\end{array}$ & $\begin{array}{l}0.103 * * * \\
(0.000)\end{array}$ & $\begin{array}{l}-0.003 \\
(0.001)\end{array}$ \\
\hline Treat & $\begin{array}{l}0.013 * * * \\
(0.000)\end{array}$ & $\begin{array}{l}0.022 * * * \\
(0.001)\end{array}$ & $\begin{array}{l}0.020 * * * \\
(0.000)\end{array}$ & $\begin{array}{l}-0.009 * * * \\
(0.001)\end{array}$ \\
\hline Post $\times$ treat & $\begin{array}{l}-0.012 * * * \\
(0.000)\end{array}$ & $\begin{array}{l}-0.014 * * * \\
(0.000)\end{array}$ & $\begin{array}{l}-0.086^{* * * *} \\
(0.000)\end{array}$ & $\begin{array}{l}-0.003 * * \\
(0.001)\end{array}$ \\
\hline Tobin's $Q$ & & $\begin{array}{l}0.003 \\
(0.002)\end{array}$ & & $\begin{array}{l}0.018 * * * \\
(0.001)\end{array}$ \\
\hline Sales growth & & $\begin{array}{l}0.005 \\
(0.002)\end{array}$ & & $\begin{array}{l}0.001 \\
(0.001)\end{array}$ \\
\hline Firm size & & $\begin{array}{l}-0.067 * * * \\
(0.003)\end{array}$ & & $\begin{array}{l}1.247 * * * \\
(0.010)\end{array}$ \\
\hline Constant & $\begin{array}{l}0.219 * * * \\
(0.000)\end{array}$ & $\begin{array}{l}1.685^{* * * *} \\
(0.069)\end{array}$ & $\begin{array}{l}4.986 * * * \\
(0.000)\end{array}$ & $\begin{array}{l}-22.882 * * * \\
(0.226)\end{array}$ \\
\hline Industry fixed effects & Yes & Yes & Yes & Yes \\
\hline Time fixed effects & Yes & Yes & Yes & Yes \\
\hline Observations & 22,349 & 22,082 & 22,882 & 21,742 \\
\hline$R^{2}$ & 0.010 & 0.139 & 0.011 & 0.894 \\
\hline
\end{tabular}

Robust standard errors in parentheses

$* * * p<0.01, * * p<0.05$

indicate that financial costs increase and profits decrease, curbing firm cash flows and creating severe financial constraints.

\section{Robustness Tests}

To identify whether the COVID-19 pandemic results in firm financial constraints, we provide several robustness tests, including placebo effect, using alternative financial constraint measurements and confirming cases, to re-estimate our regression results.

\section{Placebo Effect}

Table 6 shows the regression results after introducing the interaction term one quarter earlier and with the Post variables. Our results show that the DID effect remains positive and significant, while the interaction pre-post*Treat is insignificant. These findings suggest that potential endogeneity problems caused by 


\section{The Distribution of Confirmed COVID-19 Cases in China till 2021}

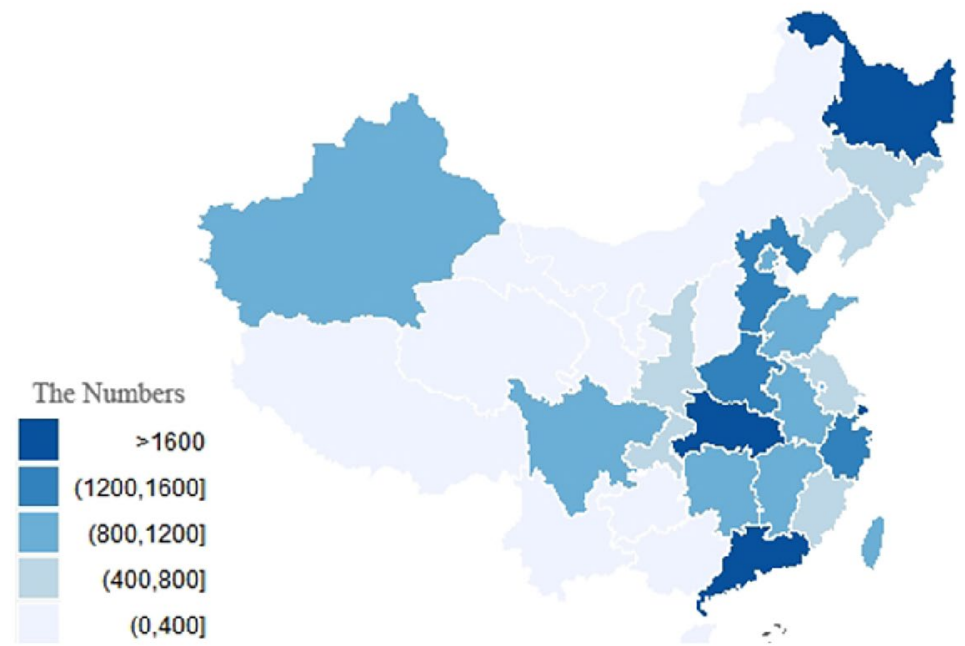

Fig. 4 Confirmed cases of COVID-19 by province

time-varying effects do not affect our baseline results, and our external shock setting and estimation results are reliable.

\section{Estimations with Alternative Measurements of Financial Constraint}

To test whether our baseline regressions are reliable with the alterative setting of financial constraints, we perform a robustness test by replacing our key explanatory variables. The indicators of financial constraint are replaced with liquidity level and SA index (Hadlock and Pierce 2010). The smaller the figure for liquidity and SA index, the more financial constraints firms face. According to the results shown in Table 7, the interaction Post*Treat is significantly negative, indicating that firms suffer from severe financial constraints under the shock of the COVID-19 pandemic. The results are consistent with the baseline regressions, indicating our baseline regressions are robust regardless of the measurement of financial constraint.

\section{Relationship Between Confirmed Cases and Financial Constraint}

Figure 4 presents the distribution of confirmed COVID-19 cases across provinces in 2021, indicating that the COVID-19 pandemic is widespread in China with differing intensity across provinces.

To capture the outbreak of the pandemic, we use the logarithm of the number of corona cases plus 1 to denote the COVID-19 pandemic (Ortmann et al. 2020). We 
Table 8 Robustness test-regression results of confirmed cases on financial constraint

\begin{tabular}{|c|c|c|c|c|}
\hline \multirow[t]{2}{*}{ Variable } & (1) & (2) & (3) & (4) \\
\hline & \multicolumn{2}{|c|}{ Financial constraints $=\mathrm{WW}$ index } & \multicolumn{2}{|c|}{$\begin{array}{l}\text { Financial constraints }=\mathrm{KZ} \\
\text { index }\end{array}$} \\
\hline \multirow[t]{2}{*}{ Numbers of confirmed cases } & $0.001 *$ & $0.001^{*}$ & $0.043 * * *$ & $0.034 * * *$ \\
\hline & $(0.001)$ & $(0.001)$ & $(0.007)$ & $(0.006)$ \\
\hline \multirow[t]{2}{*}{ Tobin's $Q$} & & $-0.006^{* * *}$ & & -0.010 \\
\hline & & $(0.001)$ & & $(0.012)$ \\
\hline \multirow[t]{2}{*}{ Sales growth } & & $0.041 * * *$ & & $0.058 * * *$ \\
\hline & & $(0.001)$ & & $(0.010)$ \\
\hline \multirow[t]{2}{*}{ Firm size } & & $0.007 * * *$ & & $0.418 * * *$ \\
\hline & & $(0.001)$ & & $(0.008)$ \\
\hline \multirow[t]{2}{*}{ Constant } & $1.097 * * *$ & $1.008 * * *$ & $7.022 * * *$ & $-2.532 * * *$ \\
\hline & $(0.004)$ & $(0.020)$ & $(0.553)$ & $(0.452)$ \\
\hline Industry fixed effects & Yes & Yes & Yes & Yes \\
\hline Time fixed effects & Yes & Yes & Yes & Yes \\
\hline Observations & 15,459 & 15,459 & 14,672 & 14,672 \\
\hline$R^{2}$ & 0.024 & 0.130 & 0.024 & 0.301 \\
\hline
\end{tabular}

Robust standard errors in parentheses

$* * * p<0.01, * p<0.1$

use fixed effects to explore the relationship between confirmed cases and financial constraints. As shown in Table 8, the coefficients of the core variable, Numbers of Confirmed Cases, are significantly positive, indicating that the spread of COVID-19 causes firms to suffer from strong financial constraints. The results are consistent with the baseline regressions.

\section{Conclusions}

This paper comprehensively explores the impact of the COVID-19 pandemic on firm financial constraints by examining firm-level performance, and further discusses the mechanisms involved. We further investigate SDG performance as measured by ESG performance, which alleviates firm financial constraints.

This study reaches several findings through incorporating a Chinese listed firm database matched with ESG performance scores and using DID estimation. First, the negative impact of the COVID-19 pandemic on financial performance is substantial, and the pandemic plays a negative and significant role in financial constraints, including the WW index, KZ index, liquidity, and SA index. Second, regarding the role of ESG on financial constraints alleviation, the negative impact of the pandemic on financial 
constraints is significantly improved by better ESG performance. Third, with respect to the performance of different financial intermediaries, we find that better ESG-performing firms can increase both internal and external financial intermediation, including liquidity and both short- and long-term debt, alleviating firm financial constraints. Finally, we generate evidence that the COVID-19 pandemic hurts firm performance with respect to financial costs and profitability.

Our main results hold several important implications for government regulators, policy makers, and corporate managers. Government regulators and policy makers can facilitate, promote, and encourage ESG disclosure, leading to increased capital allocation efficiency and lower corporate financing costs. They should continuously encourage and regulate firms toward disclosing their ESG information. Managerial implications can be derived from this paper as well. Strong ESG performance can play a signal role in raising financial resources in the capital markets. In this regard, corporate managers should be attentive to ESG performance in production and management processes.

Acknowledgements This work is supported by the National Natural Science Foundation of China (NO. 72103147). This work is also supported by Beijing High-level Returned Overseas Talents Funding Project (Dongyang Zhang).

\section{References}

Abdi, H., and M.A.B. Omri. 2020. Web-based disclosure and the cost of debt: MENA countries evidence. Journal of Financial Reporting \&amp; Accounting 18 (3): 533-561. https://doi.org/10.1108/ JFRA-07-2019-0088.

Ahmed, D.A.H., Y. Eliwa, and D.M. Power. 2019. The impact of corporate social and environmental practices on the cost of equity capital: UK evidence. International Journal of Accounting \&amp; Information Management 27 (3): 425-441. https://doi.org/10.1108/IJAIM-11-2017-0141.

Albarrak, M.S., M. Elnahass, and A. Salama. 2019. The effect of carbon dissemination on cost of equity. Business Strategy \&amp; the Environment 28 (6): 1179-1198. https://doi.org/10.1002/bse.2310.

Ali, M., N. Alam, and S.A.R. Rizvi. 2020. Coronavirus (COVID-19)—An epidemic or pandemic for financial markets. Journal of Behavioral and Experimental Finance 27: 100341. https://doi.org/10. 1016/j.jbef.2020.100341.

Amarjit, G., A. Amiraslany, J. Obradovich, and N. Mathur. 2019. Efficient working capital management, bond quality rating, and debt refinancing risk. Managerial Finance 45 (7): 869-885.

Amel-Zadeh, A., and G. Serafeim. 2018. Why and how investors use ESG information: Evidence from a global survey. Financial Analysts Journal 74 (3): 87-103. https://doi.org/10.2469/faj.v74.n3.2.

Baek, S., S.K. Mohanty, and M. Glambosky. 2020. COVID-19 and stock market volatility: An industry level analysis. Finance Research Letters 37: 101748. https://doi.org/10.1016/j.frl.2020.101748.

Baker, S.R., N. Bloom, S.J. Davis, and S.J. Terry. 2020. COVID-induced economic uncertainty. National Bureau of Economic Research Working Papers: 26983. Retrieved from: http://search.ebscohost. com/login.aspx ?direct=true \&db=eoh\&AN=1860535\&lang=zh-cn\&site=ehost-live $\quad$ http://www. nber.org/papers/w26983.pdf.

Banerjee, R., K. Gupta, and P. Mudalige. 2020. Do environmentally sustainable practices lead to financially less constrained firms? International evidence. International Review of Financial Analysis 68: 101337. https://doi.org/10.1016/j.irfa.2019.03.009.

Branco, M., and L. Rodrigues. 2006. Corporate social responsibility and resource-based perspectives. Journal of Business Ethics 69 (2): 111-132. https://doi.org/10.1007/s10551-006-9071-z.

Brown, S., and S.A. Hillegeist. 2007. How disclosure quality affects the level of information asymmetry. Review of Accounting Studies 12 (2): 443-477. https://doi.org/10.1007/s11142-007-9032-5. 
Chams, N., and J. García-Blandón. 2019. On the importance of sustainable human resource management for the adoption of sustainable development goals. Resources, Conservation \&amp; Recycling 141: 109-122. https://doi.org/10.1016/j.resconrec.2018.10.006.

Chen, H.-Y., and S.S. Yang. 2020. Do investors exaggerate corporate ESG information? Evidence of the ESG momentum effect in the Taiwanese market. Pacific-Basin Finance Journal 63: 101407. https:// doi.org/10.1016/j.pacfin.2020.101407.

Ding, X., C. Zhou, V. Mauerhofer, W. Zhong, and G. Li. 2019. From environmental soundness to sustainable development: Improving applicability of payment for ecosystem services scheme for diverting regional sustainability transition in developing countries. Sustainability 11 (2): 361. https://doi.org/ $10.3390 /$ su11020361.

Eccles, N., and S. Viviers. 2011. The origins and meanings of names describing investment practices that integrate a consideration of ESG issues in the academic literature. Journal of Business Ethics 104 (3): 389-402. https://doi.org/10.1007/s10551-011-0917-7.

Fatemi, A., M. Glaum, and S. Kaiser. 2018. ESG performance and firm value: The moderating role of disclosure. Global Finance Journal 38: 45-64. https://doi.org/10.1016/j.gfj.2017.03.001.

Friede, G., T. Busch, and A. Bassen. 2015. ESG and financial performance: Aggregated evidence from more than 2000 empirical studies. Journal of Sustainable Finance \&amp; Investment 5 (4): 210233. https://doi.org/10.1080/20430795.2015.1118917.

Garcia, A.S., W. Mendes-Da-Silva, and R.J. Orsato. 2017. Sensitive industries produce better ESG performance: Evidence from emerging markets. Journal of Cleaner Production 150: 135-147. https:// doi.org/10.1016/j.jclepro.2017.02.180.

Goodell, J.W. 2020. COVID-19 and finance: Agendas for future research. Finance Research Letters 35 (3): 101512.

Grainger-Brown, J., and S. Malekpour. 2019. Implementing the sustainable development goals: A review of strategic tools and frameworks available to organisations. Sustainability 11 (5): 1-18.

Granziera, E., and T. Sekhposyan. 2019. Predicting relative forecasting performance: An empirical investigation. International Journal of Forecasting 35 (4): 1636-1657.

Griskevicius, V., J.M. Ackerman, S.M. Cantú, A.W. Delton, T.E. Robertson, J.A. Simpson, and J.M. Tybur. 2013. When the economy falters, do people spend or save? Responses to resource scarcity depend on childhood environments. Psychological Science 24 (2): 197-205. https://doi.org/10.1177/ 0956797612451471.

Gu, X., S. Ying, W. Zhang, and Y. Tao. 2020. How do firms respond to COVID-19? First evidence from Suzhou, China. Emerging Markets Finance and Trade 56 (10): 2181-2197.

Hadlock, C.J., and J.R. Pierce. 2010. New evidence on measuring financial constraints: Moving beyond the KZ index. Review of Financial Studies 23 (5): 1909-1940. https://doi.org/10.1093/rfs/hhq009.

Harford, J., S. Klasa, and W.F. Maxwell. 2014. Refinancing risk and cash holdings. Journal of Finance 69 (3): 975-1012.

Hassan, M.M., M.A. Kalam, S. Shano, M.R. Khan Nayem, M.K. Rahman, S.A. Khan, and A. Islam. 2020. Assessment of epidemiological determinants of COVID-19 pandemic related to social and economic factors globally. Journal of Risk \&amp; Financial Management 13 (9): 1-14.

He, P., H. Niu, Z. Sun, and T. Li. 2020. Accounting index of COVID-19 impact on Chinese industries: A case study using big data portrait analysis. Emerging Markets Finance and Trade 56 (10): 2332-2349.

$\mathrm{Hu}$, S., and D. Gong. 2019. Economic policy uncertainty, prudential regulation and bank lending. Finance Research Letters 29: 373-378. https://doi.org/10.1016/j.frl.2018.09.004.

Just, M., and K. Echaust. 2020. Stock market returns, volatility, correlation and liquidity during the COVID-19 crisis: Evidence from the Markov switching approach. Finance Research Letters 37: 101775. https://doi.org/10.1016/j.frl.2020.101775.

Kyriazis, NA. 2021. Investigating the nexus between European major and sectoral stock indices, gold and oil during the COVID-19 pandemic. SN Business \&amp; Economics 1 (4): 57. https://doi.org/10. 1007/s43546-021-00060-x.

Lamont, O., C. Polk, and J. Saa-Requejo. 2001. Financial constraints and stock returns. Review of Financial Studies 14 (2): 529-554.

Li, W., F. Chien, H.W. Kamran, T.M. Aldeehani, and F. Taghizadeh-Hesary. 2021. The nexus between covid-19 fear and stock market volatility. Ekonomska Istraživanja/Economic Research 1-22.

Milea, C. 2020. Consequences of COVID-19 on the international trade in goods and services: Forecasts, developments, restrictions. Financial Studies 24 (4): 29-40. 
Opler, T., L. Pinkowitz, R. Stulz, and R. Williamson. 1999. The determinants and implications of corporate cash holdings. Journal of Financial Economics 52 (1): 3-46. https://doi.org/10.1016/S0304405X(99)00003-3.

Ortmann, R., M. Pelster, and S.T. Wengerek. 2020. COVID-19 and investor behavior. Finance Research Letters 37: 101717. https://doi.org/10.1016/j.frl.2020.101717.

Pedersen, L.H., S. Fitzgibbons, and L. Pomorski. 2020. Responsible investing: The ESG-efficient frontier. Journal of Financial Economics. https://doi.org/10.1016/j.jfineco.2020.11.001.

Phan, D.H.B., and P.K. Narayan. 2020. Country responses and the reaction of the stock market to COVID-19-A preliminary exposition. Emerging Markets Finance and Trade 56 (10): 2138-2150.

Rizwan, M.S., G. Ahmad, and D. Ashraf. 2020. Systemic risk: The impact of COVID-19. Finance Research Letters 36: 101682. https://doi.org/10.1016/j.frl.2020.101682.

Shah, A.K., S. Mullainathan, and E. Shafir. 2012. Some consequences of having too little. Science 338 (6107): 682-685. https://doi.org/10.1126/science.1222426.

Sharma, E., N. Mazar, A.L. Alter, and D. Ariely. 2014. Financial deprivation selectively shifts moral standards and compromises moral decisions. Organizational Behavior and Human Decision Processes 123 (2): 90-100. https://doi.org/10.1016/j.obhdp.2013.09.001.

Shen, H., M. Fu, H. Pan, Z. Yu, and Y. Chen. 2020. The impact of the COVID-19 pandemic on firm performance. Emerging Markets Finance and Trade 56 (10): 2213-2230. https://doi.org/10.1080/15404 96X.2020.1785863.

Taghizadeh-Hesary, F., N. Yoshino, and P. Han. 2021. Analyzing the characteristics of green bond markets to facilitate green finance in the post-covid-19 world. Sustainability 13 (10): 5719.

Tamimi, N., and R. Sebastianelli. 2017. Transparency among S\&P 500 companies: An analysis of ESG disclosure scores. Management Decision 55 (8): 1660-1680. https://doi.org/10.1108/ MD-01-2017-0018.

Vidya, C.T., and K.P. Prabheesh. 2020. Implications of COVID-19 pandemic on the global trade networks. Emerging Markets Finance and Trade 56 (10): 2408-2421. https://doi.org/10.1080/15404 96X.2020.1785426.

Whited, T.M., and G. Wu. 2006. Financial constraints risk. Review of Financial Studies 19 (2): 531-559. https://doi.org/10.1093/rfs/hhj012.

Wong, W.C., J.A. Batten, A.H. Ahmad, S.B. Mohamed-Arshad, S. Nordin, and A.A. Adzis. 2021. Does ESG certification add firm value? Finance Research Letters 39: 101593. https://doi.org/10.1016/j. frl.2020.101593.

Xiong, H., Z. Wu, F. Hou, and J. Zhang. 2020. Which firm-specific characteristics affect the market reaction of Chinese listed companies to the COVID-19 pandemic? Emerging Markets Finance and Trade 56 (10): 2231-2242. https://doi.org/10.1080/1540496X.2020.1787151.

Yoshino, N., and M. Otsuka. 2021. Covid-19 and optimal portfolio selection for investment in sustainable development goals. Finance Research Letters 38: 101695.

Zeug, W., A. Bezama, U. Moesenfechtel, A. Jähkel, and D. Thrän. 2019. Stakeholders' interests and perceptions of bioeconomy monitoring using a sustainable development goal framework. Sustainability 11 (6): 1-24.

Zhang, D. 2020a. Do credit squeezes influence firm survival? An empirical investigation of China. Economic Systems 44 (3): 100790. https://doi.org/10.1016/j.ecosys.2020.100790.

Zhang, D. 2020b. How do firms overcome financial constraint anxiety to survive in the market? Evidence from large manufacturing data. International Review of Financial Analysis 70: 101503. https://doi. org/10.1016/j.irfa.2020.101503.

Zhang, D. 2021. Does a designed financial system impact polluting firms' employment? Evidence of an experimental economic policy. Finance Research Letters 38: 101500.

Zhang, H., and Z. Hu. 2021. How does COVID-19 affect firms' short-term financial pressure? Evidence from China. Applied Economics Letters. https://doi.org/10.1080/13504851.2021.1886234.

Zhang, D., and S.A. Vigne. 2021. The causal effect on firm performance of China's financing-pollution emission reduction policy: Firm-level evidence. Journal of Environmental Management 279: 111609. https://doi.org/10.1016/j.jenvman.2020.111609.

Publisher's Note Springer Nature remains neutral with regard to jurisdictional claims in published maps and institutional affiliations. 